\title{
Inverter Dead-Time Compensation and Control Scheme for Reducing Harmonic Distortion and Improving Conversion Efficiency
}

\author{
Zhongwei Guo Member (Nagasaki University, Shindengen Electric Mfg. Co., Ltd.) \\ Fujio Kurokawa Senior Member (Nagasaki University)
}

Keywords: PWM inverter, LC filter, dead-time compensation, sliding mode control, conversion efficiency

A renewable energy system usually uses a grid-connected inverter to interface with the utility grid. To promote the use of such systems, grid-connected inverters with low harmonic distortion and high efficiency are required.

Fig. 1 shows the circuit configuration of a single-phase three-wire grid-connected inverter. The circuit uses a DC/DC converter to boost a low dc voltage to the dc-link voltage required for inverter operations. In inverter circuits, dead-time is necessary to prevent short-circuits in the dc-link voltage source. The dead-time results in output quality deviations and hinders dc-link voltage utilization. Many dead-time compensation methods have been investigated for use in motor drive applications. Usually, the current polarity is used to compensate for the dead-time effect. However, for the inverters with an LC filter, especially when a small inductor is used, the compensation using the current polarity may deteriorate the output quality.

In this paper, the dead-time mechanism of inverters with an LC filter is analyzed, and a mathematical model is presented. Using this model, we propose a new current control scheme involving the use of a PI controller and a sliding mode controller (SMC).

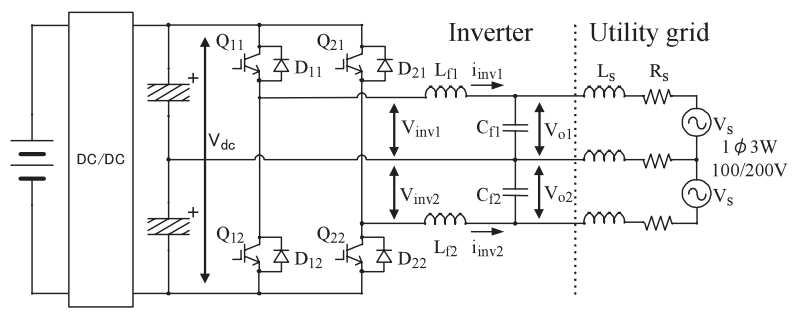

Fig. 1. $1 \phi 3 \mathrm{~W}$ grid-connected inverter circuit
Fig. 2 shows the proposed current controller configuration. The PI controller controls the inverter when the inverter operates in the linear region. With a sliding mode function, the SMC detects deadtime nonlinear operations and outputs the dead-time error voltage for dead-time compensation. Depending on the SMC output, the upper side switch or the lower side switch can be kept off, and the counter side switch can be controlled up to a PWM duty of $100 \%$, with a smooth transition between different dead-time operation modes. The proposed scheme maximizes the dc-link voltage utilization and greatly improves the conversion efficiency.

The validity of the control scheme is confirmed by simulation and experimental results. The experimental results show that harmonic distortion is decreased to $1 / 3-1 / 2$ of that in the conventional PI controller, the dc-link voltage can be reduced by about $10 \%$, and an improvement of $1.6 \%$ is achieved in the efficiency.

Fig. 3 shows a comparison current waveform of the proposed controller with that of the conventional one.

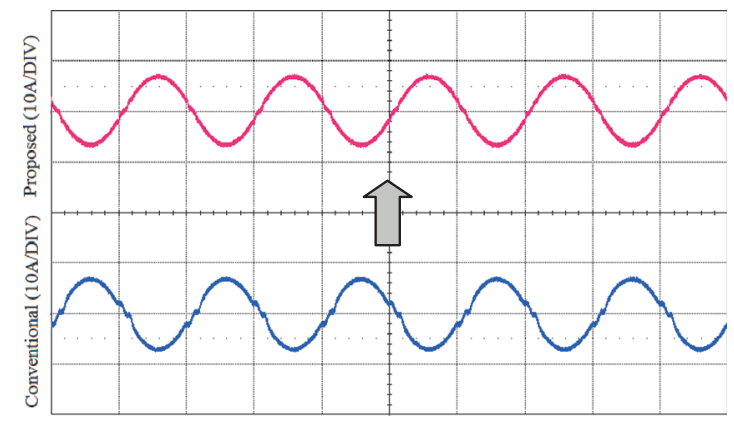

Fig. 3. Experimental waveforms of output current for the proposed and conventional PI controller

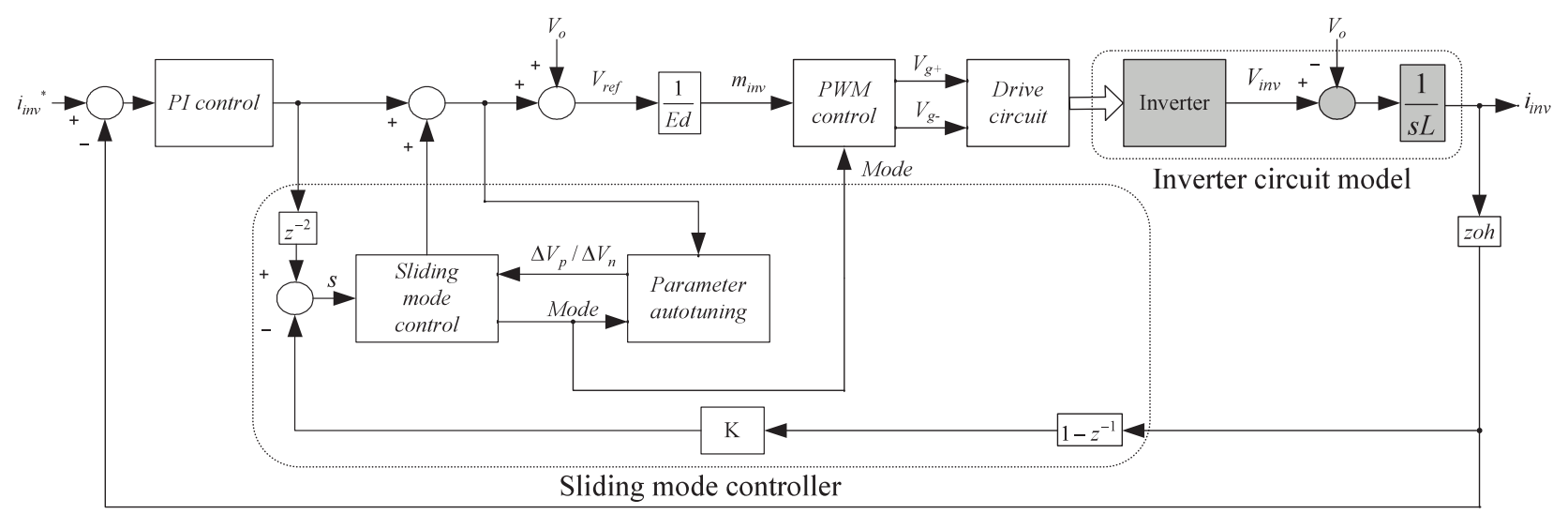

Fig. 2. Configuration of the proposed controller 


\title{
系統連系インバータのデッドタイム補償及び 効率改善のための制御方法
}

\author{
正員郭 中為*,** 上級会員 黒川不二雄*,*** \\ Inverter Dead-Time Compensation and Control Scheme for Reducing Harmonic Distortion \\ and Improving Conversion Efficiency \\ Zhongwei Guo ${ }^{*, * *}$, Member, Fujio Kurokawa,****, Senior Member
}

\begin{abstract}
In PWM inverters, dead-time is necessary to prevent short-circuits in the power supply; the dead-time results in output quality deviations and hinders dc-link voltage utilization. In this paper, the dead-time mechanism of inverters with an LC filter is analyzed, and a mathematical model is presented. Using this model, we propose a new current control scheme involving the use of a PI controller and a sliding mode controller. Depending on the sliding mode controller output, the upper side switch or the lower side switch can be kept off, and the counter side switch can be controlled up to a PWM duty of $100 \%$, with a smooth transition between different dead-time operation modes. The scheme maximizes the dc-link voltage utilization and improves the conversion efficiency. Experimental results show that harmonic distortion is decreased to $1 / 3-1 / 2$ of that in the conventional PI control scheme, the dc-link voltage can be reduced by about $10 \%$, and an improvement of $1.6 \%$ is achieved in the efficiency.
\end{abstract}

キーワード : PWM インバータ, LCフィルタ, デッドタイム補償, スライディングモード制御, 変換効率

Keywords: PWM inverter, LC filter, dead-time compensation, sliding mode control, conversion efficiency

\section{1. まえがき}

地球温暖化環境問題への取り込みとして，太陽光，風力 などの再生可能エネルギーの利用が促進されている。この ようなエネルギーは日照や風など自然条件に対応して変化 するため, 単独で負荷装置へ安定な電力を供給することは できないという問題がある。商用電源と連系しながら負荷 へ安定な電力を供給すると共に余剩の電力を商用系統へ売 電する系統連系インバータが必要とされている。

このような系統連系インバータ装置が大量に導入された 場合に, 出力高調波歪みの影響により商用系統の電圧品質 の低下が懸念される。このため, 系統連系インバータに低

\footnotetext{
* 長崎大学大学院生産科学研究科

干 852-8521 長崎市文教町 1-14

Graduate School of Science and Technology, Nagasaki University

1-14, Bunkyo-machi, Nagasaki 852-8521

** 新電元工業 (株)

于 357-8585 飯能市南町 10-13

Shindengen Electric Mfg. Co., Ltd.

10-13, Minami-cho, Hanno 357-8585

*** 長崎大学工学部電気電子工学科

干 852-8521 長崎市文教町 1-14

Department of Electrical and Electronic Engineering, Nagasaki University

1-14, Bunkyo-machi, Nagasaki 852-8521
}

歪みな正弦波電流出力が要求されている。高調波抑制対策 と共に, CO2 削減が目的であるため損失の少ない高効率実 現技術は系統連系インバー夕の重要な研究課題である。

太陽光発電などに使用される系統連系インバー夕は太陽 光パネルなどから提供される低い電圧を DC/DC コンバー 夕で昇圧し, インバー夕部でその直流電圧を必要な交流電 力に変換している。通常，インバータ回路の上下スイッチ を交互にオン・オフするように制御している。上下スイッ チの同時オンによるアーム短絡を防止するために，スイッ チングする時に, 上下スイッチを同時オフする期間, 即ち, デッドタイム期間を設ける必要がある。このデッドタイム の影響により，インバータシステムの動作が非線形動作と なるため, 線形モデルを基づいた検討で理想な制御性能が得 られないと考える。回転機制御を対象に, 現在まで多くの デッドタイム補償法が提案されている(1) (7)。文献 $(1) \sim(5)$ は電流の極性で誤差電圧のフィードフォワードによるデッ ドタイム補償を行っている。また, モー夕低速運転領域に 電流極性だけでのデッドタイム補償は不十分であるため, 文献(6) (7) は外乱オブザーバを用いてデッドタイム補償を 行うことで低速回転領域の特性改善を図っている。回転機 負荷用インバータの場合, インバータの出力端に大きなイ ンダクタが接続されることとみなすことができ, スイッチ ングリップル電流が小さい。出力電流のゼロクロッシング 
期間が短いため，電流極性でのデッドタイム補償が有効な 方法と考える。しかし，LCフィルタ付けインバータ，特に 低コストのため，ACフィルタに小容量インダクタが採用 された場合はインダクタリップル電流が大きい，インダク 夕に流れるインバー夕出力電流が極性を交代しながら負荷 に電流を供給する期間が長いという特徵がある。この期間 において，一方のスイッチがオフされた時はブリッジ回路 の反対側スイッチのダイオードが自動的にオンされる，そ のため，PWM ゲート信号にデッドタイムを挿入しても動 作結果を影響しない，即ちデッドタイム誤差電圧が発生し ない。デッドタイム誤差が発生しないため，平均值電流の 極性によるデッドタイム補償を行う場合は逆に特性を悪化 する恐れがある。また，文献 (6) (7) に提案された外乱オブ ザーバ法は低速回転のモータ駆動インバー夕に有効と考え るが，DSP コントローラの場合に制御演算及び制御結果が サンプリング值に反映されるまでの遅れ時間の影響により， 外乱オブザーバを高速化するのは困難と考える。また，系 統連系インバータのような逆変換電源装置に対して正弦波 波形出力が要求されている。モータの漏れインダクタンス のようにフィルタの役目をするデバイスが負荷側に存在し ないため，ACフィルタをインバータ内部に搭載する必要 がある。ACフィルタのインダクタは高価な回路素子なの で，できる限り低コストの小容量のインダクタを採用する 必要がある。この場合に，インバータと商用系統との間の インピーダンスは非常に小さいため，僅かな制御信号のず れでも大きな電流制御誤差をもたらす，安定な制御を実現 するため，外乱オブザーバ法をこのような装置へ適用する 場合はさらに低速化する必要がある。即ち，高性能なデッ ドタイム補償を実現することは困難と考える。

さらに，前述の従来の文献では，回転機駆動インバー夕 を対象にデッドタイム誤差電圧が出力電流の極性により符 号が変化することが報告されている。インバータの出力端 に大容量なインダクタンスが接続されていることを前提と した近似した表現であり，小容量インダクタで構成される $\mathrm{AC}$ フィルタが搭載するインバータの場合は電流極性だけ ではなく，スイッチングリップル電流の大きさによりある 電流範囲で誤差電圧が変化するものであり，5つの動作モー ドに分ける必要がある。その数式モデルについての報告は ないようである。

デッドタイムの影響で，スイッチング PWM 信号の有効 オンデューティを $100 \%$ までリニアに出力することは出来 ないため，直流リンク電圧の利用率が低下し，デッドタイ ムの必要ない理想スイッチに比べ，高い直流リンク電圧が 必要とされている。結果として，回路素子に高い耐圧を要 求すると共に，スイッチングロスの増加をもたらす ${ }^{(8)}$ 。

さらに，IGBT スイッチング素子が採用された場合には， IGBT ダイオードを通して電流が流れる動作モードがあっ て，この期間にIGBTをオン・オフ制御する必要はない。 常にオン・オフ制御する場合は，無駄なドライブロスが発 生すると共に，IGBT がオフされる時にゲートの残留電荷
によりターンオフ損失が大きいという問題がある(9)。

本論文では，LCフィルタ付インバータのデッドタイム により生じる誤差電圧のメカニズムを明らかにし，従来の PI 制御に加えてスライディングモード制御を併用すること で，出力高調波歪みを改善すると共に，直流リンク電圧の 低減及び变換効率の向上を図る。この提案方式では, 線形 動作領域の動作はPI 制御器により制御し, デッドタイムに よる非線形動作が検出された場合には数式モデルより得ら れた結果を基にスライディングモード制御器を設計するこ とで，非線形動作の悪影響を排除できる。これにより，歪 み率の改善を図っている。スライディングモード制御のパ ラメータを自己調整することで，回路パラメータ及び動作 条件変化への適応制御を図っている。スライディングモー ド制御器の出力を基に, IGBT スイッチの必要のないゲー トオン信号をなくすことができるため，ターンオフロスを 低減すると共に，デッドタイム期間を無くすことができる。 スイッチの実効オンデューティを $100 \%$ ま゙リニアに出力 することができ, 直流リンク電圧利用率を最大にすること ができる。これにより，直流リンク電圧の低減及び効率改 善を図っている。シミュレーションと実験により，その効 果を検証したので，その内容について述べる。第 2 章では, 回路の構成及び従来の問題点, 第 3 章では, デッド夕イム解 析及び直流リンク電圧設計法，第 4 章では，提案する制御 器の実現方法, 第 5 章では, 単相 3 線式系統連系インバー 夕を用いたシミュレーション結果, 第 6 章では, 実験結果, 第 7 章をまとめとする。

\section{2. 回路構成及び従来問題の説明}

〈2·1〉インバータ回路及び制御構成図 1 に単相 3 線式系統連系インバータの回路構成を示す。ここで, $\mathrm{V}_{\mathrm{dc}}$ は 直流リンク電圧, $\mathrm{L}_{\mathrm{f}}$ 及び $\mathrm{C}_{\mathrm{f}}$ はそれぞれ出力フィルタのイ ンダクタとコンデンサである。 $\mathrm{L}_{\mathrm{s}}$ 及び $\mathrm{R}_{\mathrm{s}}$ はそれぞれ, 配 電線など系統側のインダクタンス, 抵抗インピーダンスを 示す。

図 2 に電流制御の構成を示す。ここで，インバー夕回路 は連続時間モデルで表し， $\mathrm{s}$ はラプラス演算子である。 $i_{i n v}^{*}$ は上位系からのインダクタ電流指令であり, 計測されたイ ンダクタ電流 $i_{i n v}$ をそれに一致させるために, 変調制御信 号 $m_{i n v}$ を演算するための制御信号 $u$ を決定する。制御系に

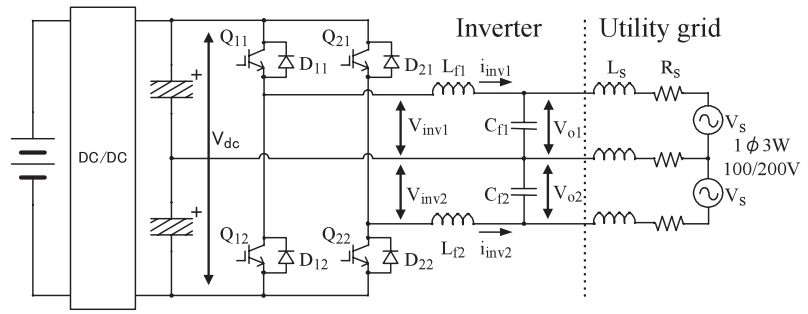

図 1 単相 3 線式系統連系インバー夕回路構成 Fig. 1. $1 \phi 3 \mathrm{~W}$ grid-connected inverter circuit configuration. 


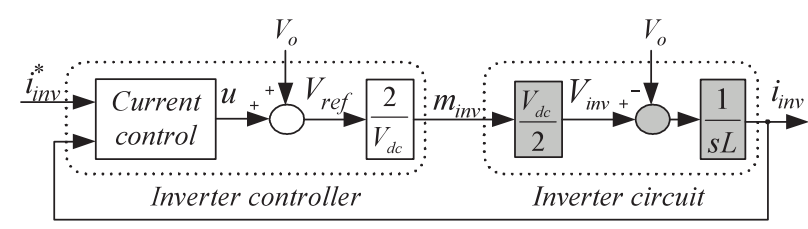

図 2 インバー夕電流制御（従来制御）

Fig. 2. Inverter current controller configuration.

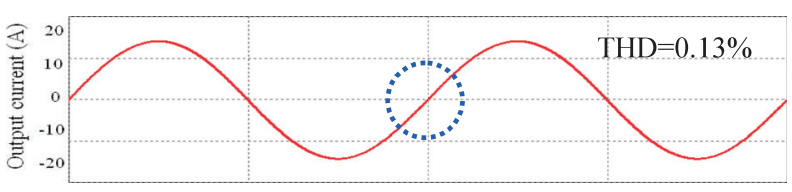

(a) Conventional PI and ideal switch (Dead-time: $0 \mu \mathrm{s}$ )

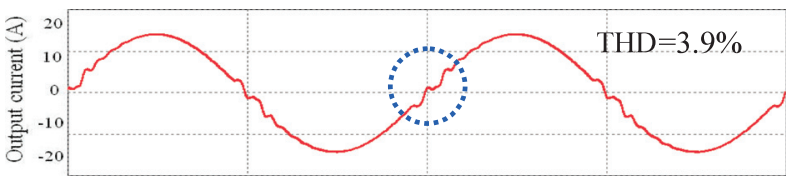

(b) Conventional PI, dead-time: $3 \mu \mathrm{s}$

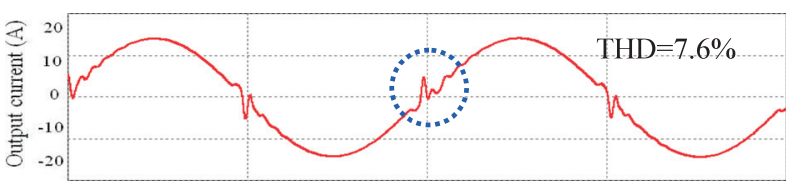

(c) Conventional PI using current polarity compensation, dead-time: $3 \mu \mathrm{s}$

図 3 出力電流波形比較

Fig. 3. Output current comparison.

使用される $V_{o}$ 及び $V_{d c}$ はそれぞれ, 系統電圧及び直流リ ンク電圧の計測結果である。図 2 の $V_{r e f}$ と $V_{i n v}$ はそれぞ れ，変調信号を作成するためのインバー夕出力電圧指令と インバータ出力電圧のキャリア周期平均である。ハイ側ス イッチ $\left(\mathrm{Q}_{11}, \mathrm{Q}_{21}\right)$ のオンデューティは (1) 式で計算され る。ロー側スイッチ $\left(\mathrm{Q}_{12}, \mathrm{Q}_{22}\right)$ のゲート信号はハイ側ス イッチの相補出力とする。ただ，短絡防止のため，一方 のスイッチをオフにしてから，反対側スイッチをオンする までにデッドタイムを挿入する必要がある。

$$
D=\left(m_{i n v}+1\right) / 2
$$

$\langle\mathbf{2} \cdot \mathbf{2}\rangle$ 従来問題の説明図 3(a) 及び図 3(b) にデッ ドタイムは必要ない理想スイッチの場合と $3 \mu \mathrm{s}$ のデッドタ イムを挿入した場合の出力電流のシミュレーション結果を 示す。デッドタイムの影響でゼロクロス付近の電流波形が 大きく歪んでしまう問題がある。また，図 3(c) に出力電流 指令の極性に応じてデッドタイム補償を行う場合のシミュ レーション結果を示す。小容量インダクタが採用される場 合には波形が改善されるのではなく，逆に波形歪みが大き くなることが分かる。

図 4(b) 及び図 4(c) に直流リンク電圧が図 4(a) のように 変化する時の出力電流波形を示す。デッドタイムは必要な い図 4(b) の場合, 直流リンク電圧は $285 \mathrm{~V}$ 以上の領域に歪 みの少ない電流が出力されている。それに対して， $3 \mu \mathrm{s}$ の デッドタイムが挿入された場合, 直流リンク電圧は $320 \mathrm{~V}$

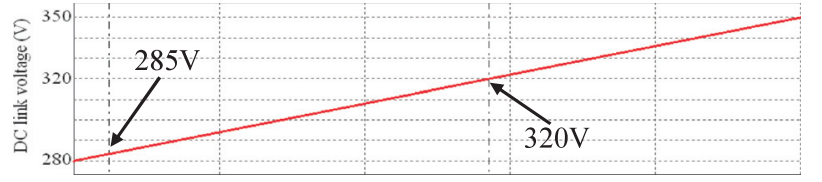

(a) DC link voltage changes $(280 \mathrm{~V} \sim 380 \mathrm{~V})$

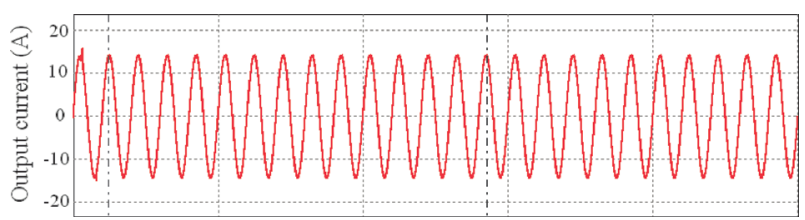

(b) Output current waveform (Ideal switch)

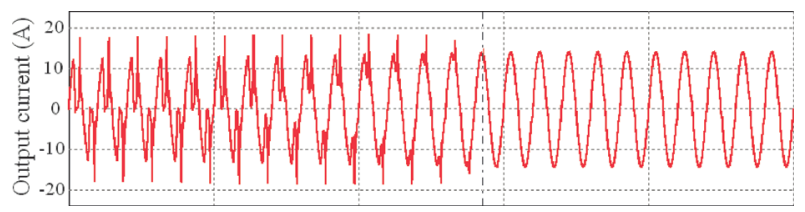

(c) Output current waveform (Dead-time: $3 \mu \mathrm{s}$ )

図 4 直流リンク電圧変化時の出力波形比較 (従来制御)

Fig. 4. Output current with conventional PI controller.

以下のときに, 出力電流が大きく歪んでしまう問題がある。 高い出力電圧を得るために，モータドライブインバータを 対象に過変調制御技術が利用されている ${ }^{(10)}$, 高い出力電圧 実効值が得られるが, 次数の低い高調波電圧が出力される 問題がある。系統連系インバー夕は正弦波電流を出力する ことは目的であり, 低歪みな出力電流が要求されている ${ }^{(11)}$ 。 商用系統は低インピーダンスの交流電圧源と見なすことが できるため, 系統連系インバータ回路と商用系統の間は配 線インピーダンス以外に, ACフィルタのインダクタンスし かない。特に小容量のインダクタが採用された場合に, 僅 かな高調波電圧でも，大きな高調波電流をもたらす。本論 文はデッドタイムの影響を排除し，リニア性を維持しなが ら IGBT スイッチの実効オンデューティを $100 \%$ ま゙出力 できる方法を提案し，直流リンク電圧の最小化を図る。

\section{3. デッドタイム解析及び直流リンク電圧設計法}

〈3・1〉 デッドタイム誤差電圧デッドタイム期間中 のスイッチ動作は制御器の制御指令に従うことはなく, 電 流方向及びその大きさに決定される。結果として, 制御器 の制御信号と実際のインバー夕端子に発生する電圧との間 に誤差が発生する。ここで, 図 5 に示す回路を用いて, デッ ドタイムの解析を行う。デッドタイム誤差電圧 $\Delta V$ (2) 式に定義するものとし, 各電流領域を対象に動作モードの 解析を行い, その数式表現を求める。

$$
\Delta V=\bar{V}_{i n v}-V_{r e f}
$$

ただし， $\bar{V}_{i n v}$ はインバータ端子と直流リンク中点間の電圧 のキャリア周期平均， $V_{r e f}$ は制御系演算結果のインバータ 出力電圧指令である。スイッチング素子の電圧降下を 0 と して, 解析を進める。 


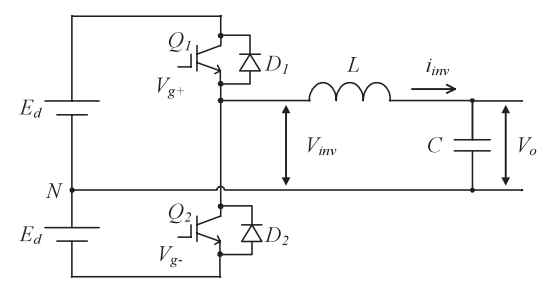

図 5 デッドタイム動作解析用回路構成

Fig. 5. Circuit configuration for dead time analysis.

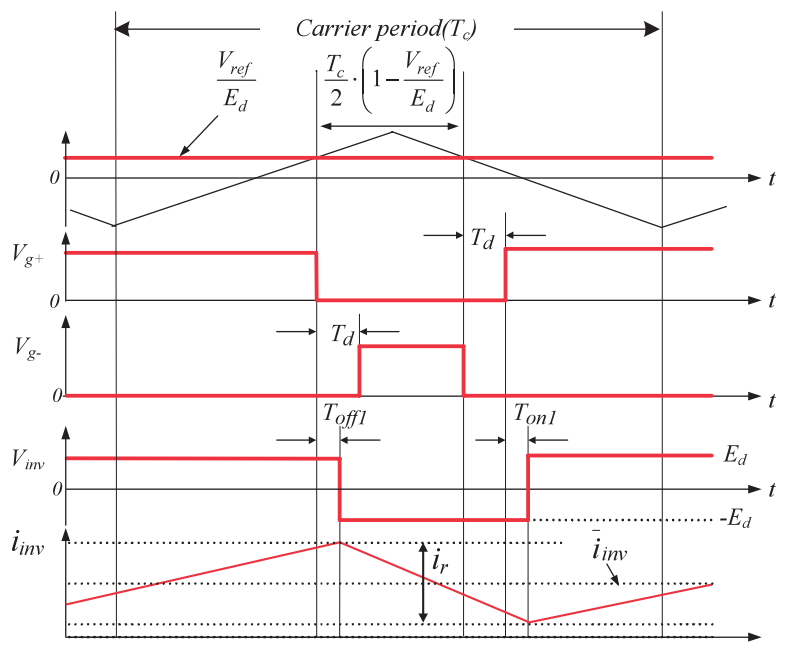

図 6 デッドタイム誤差電圧モード $1: \bar{i}_{i n v} \geq i_{r} / 2$

Fig. 6. Dead-time error mode 1 .

(1) モード $1: \bar{i}_{i n v} \geq i_{r} / 2$ ここに, $\bar{i}_{i n v}$ はインダクタ電 流の周期平均， $i_{r}$ は出力リップル電流の大きさを示す。こ の動作モードに扔いて，スイッチング期間内にインダクタ に流れる電流の極性が全て正である。図 6 に PWM ゲート 信号, インバータ端子電圧, インダク夕電流の波形を示す。 ここで, $V_{g^{+}}$: ハイ側スイッチ $\mathrm{Q}_{1}$ のゲート信号, $V_{g_{-}}$: ロー 側スイッチ $\mathrm{Q}_{2}$ のゲート信号, $V_{i n v}$ :インバータ IGBT 端子 と直流リンク中点との間の電圧信号, $i_{i n v}$ : インダクタ電流 である。インバータ出力電圧, 誤差電圧 $\Delta V$ 及びインダク 夕電流はそれぞれ，(3)〜(5) 式で表すことになる。

$$
\begin{gathered}
\bar{V}_{i n v}=V_{r e f}-\frac{T_{d}+T_{o n 1}-T_{o f f 1}}{T_{c}} \cdot 2 \cdot E_{d} \ldots \ldots \ldots \\
\Delta V=\bar{V}_{i n v}-V_{r e f}=-\frac{T_{d}+T_{o n 1}-T_{o f f 1}}{T_{c}} \cdot 2 \cdot E_{d} \\
\ldots \ldots \ldots \ldots \ldots \ldots \ldots \ldots \ldots
\end{gathered}
$$

(5) 式に扔いて，インバータの回路モデルは連続時間モデ ルで表した方がその動作が分かりやすいので，ラプラス演 算子 $\mathrm{s}$ の表現を用い，制御部に関してはディジタル制御な ので離散時間モデルとして演算子 $\mathrm{z}$ を用いている。 $1 / \mathrm{s}$ はイ ンダクタ両端に印加される電圧の時間積分を比例に電流が 変化することを意味し，(6) 式に示す積分式に置き換えるこ ともできる。

$$
i_{\text {inv }}=\int_{t 0}^{t}\left(\frac{V_{r e f}(t)+\Delta V-V_{o}(t)}{L}\right) d t+\frac{i_{r}}{2}
$$

ここで, $\mathrm{t}_{0}$ はモード 1 の開始時間, $i_{r} / 2$ はモード 1 のイン ダク夕電流の初期值である。

このときの誤差電圧は以後の説明に使用されるため, そ の大きさを正誤差電圧で表現し, 記号を $\Delta V_{p}$ で表記し, 結 果は (7) 式に示す。

$$
\Delta V_{p}=-\Delta V=\frac{T_{d}+T_{\text {on } 1}-T_{\text {off } 1}}{T_{c}} \cdot 2 \cdot E_{d} \ldots \ldots \ldots
$$

(2) モード $2: i_{r} / 2-\delta_{p}<\bar{i}_{i n v}<i_{r} / 2$ ここで, $\delta_{p}$ は (8) 式で定義し, 交流周期に変化する交流電圧により值が变化 する。

$$
\delta_{p}=\left(T_{d}+T_{o n 1}-T_{o f f 2}\right) \cdot \frac{\left(E_{d}-V_{o}\right)}{L} .
$$

説明の便宜のために， $\delta_{p}$ は正クランプ電流で表現する。 この正クランプ電流はモード 2 スイッチング周期の負ピー ク電流の最大值を示している。(8) 式の中に, $\left(E_{d}-V_{o}\right) / L$ はハイサイドスイッチがオンされる時のインダクタ電流の 時間変化率 $\mathrm{di} / \mathrm{dt}$ であり, $\left(T_{d}+T_{o n 1}-T_{o f f 2}\right)$ はローサイド スイッチ $\mathrm{Q}_{2}$ がオフされてからハイサイドスイッチ $\mathrm{Q}_{1}$ がオ ンされるまでの実効デッドタイム期間である。

図 7 及び図 8 にモード 2 に扮ける 2 つの代表的な動作 パータンのそれぞれの PWM ゲート信号，インバー夕端子 電圧, インダク夕電流の波形を示す。図 7 に示す動作パー タンでは，ローサイド IGBT がオフされるときにインダク 夕電流の極性が負であって, デッドタイム期間にハイサイ ド IGBT のダイオード $\mathrm{D}_{1}$ が導通し，インダクタ電流が負 の極性からゼロになる。そのあとのデッドタイム期間にゼ 口電流状態が保持される。図 8 に示す動作パータンでは, ローサイド IGBT がオンされる期間にダイオード $\mathrm{D}_{2}$ を通 して正の電流が流れる，デッドタイム期間に $\mathrm{Q}_{2}$ がオフさ れてもダイオード $\mathrm{D}_{2}$ が継続的に導通し，インダクタ電流 が正の極性からゼロになる，その後のデッドタイム期間は 図 7 と同じでゼロ電流状態が保持される。インダクタ平均 電流の極性が正であることと, デッドタイム期間完了の時 点にインダク夕電流がゼロであることがモード 2 の共通な 特徵である。また, 電流ゼロの期間に扔いて, インバー夕 出力電圧 $\mathrm{V}_{\mathrm{inv}}$ は $\mathrm{AC}$ フィルタのコンデンサ電圧と同じであ る。電圧指令 $\mathrm{V}_{\text {ref }}$ を $\mathrm{V}_{\mathrm{o}} \sim \mathrm{V}_{\mathrm{o}}+\Delta \mathrm{V}_{\mathrm{p}}$ の範囲で変化させた場 合にインバータ出力電流波形は変化するが, 次のスイッチ ング周期のデッドタイム期間でゼロ電流に戻ってしまう。 即ち, 変調指令を $\mathrm{V}_{\mathrm{o}} \sim \mathrm{V}_{\mathrm{o}}+\Delta \mathrm{V}_{\mathrm{p}}$ の範囲内で変化させたと きに, 次のスイッチング周期のデッドタイム期間に電流の 変化量がキャンセルされて, 出力電流が殆ど変化しない。 このモードにおいて，インバータ出力電圧のスイッチング 周期平均はコンデンサ電圧 $\mathrm{V}_{\mathrm{o}}$ と同じであって, インバー 夕出力の平均電圧と誤差電圧はそれぞれ，(9) 式と (10) 式 に示す。

$$
\bar{V}_{i n v} \doteq V_{o}
$$




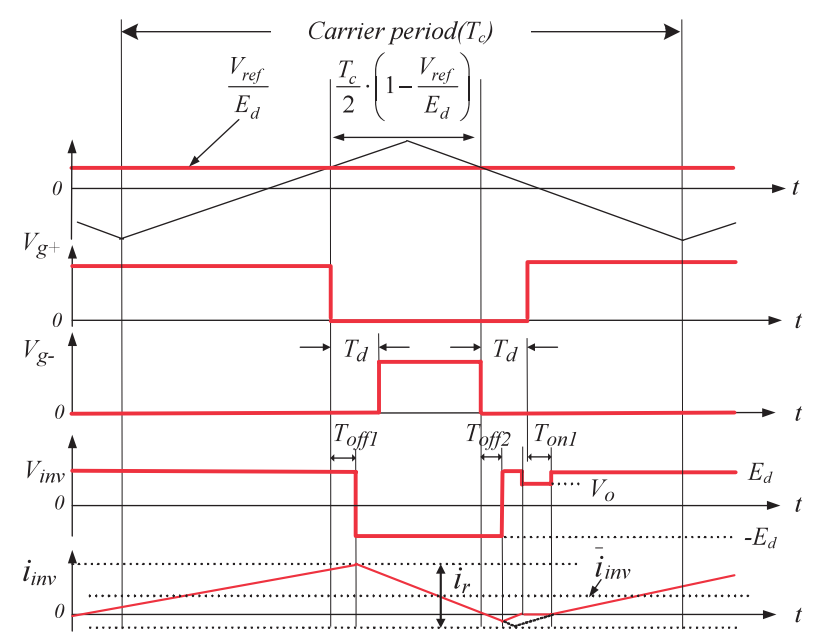

図 7 デッドタイム誤差電圧モード 2 ： $i_{r} / 2-\delta_{p}<\bar{i}_{i n v}<i_{r} / 2$ パターン 1

Fig. 7. Dead-time error mode 2, pattern 1.

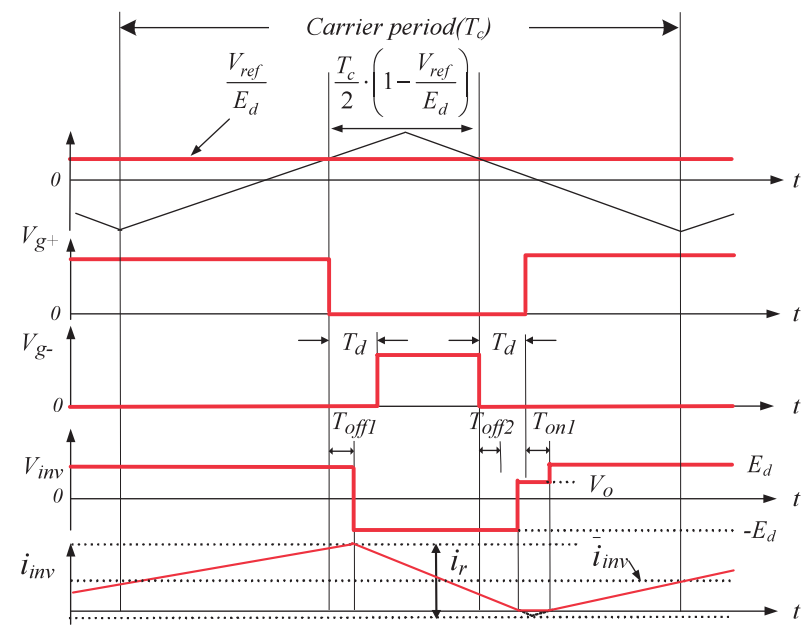

図 8 デッドタイム誤差電圧モード 2 : $i_{r} / 2-\delta_{p}<\bar{i}_{i n v}<i_{r} / 2$ パターン 2

Fig. 8. Dead-time error mode 2, pattern 2.

$$
\Delta V=\bar{V}_{i n v}-V_{r e f} \doteq V_{o}-V_{r e f}
$$

また，この動作モードでは，例えば，図 7 と図 8 の AC フィルタのコンデンサ電圧 $\mathrm{V}_{\mathrm{o}}$ が同じとすれば，電圧指令 $\mathrm{V}_{\text {ref }}$ が $\mathrm{V}_{\mathrm{o}} \sim \mathrm{V}_{\mathrm{o}}+\Delta \mathrm{V}_{\mathrm{p}}$ の範囲で変化しても, 図 7 と図 8 の $i_{r}$ の值は同じで, 変調指令 $\mathrm{V}_{\mathrm{ref}}$ の変化と比例に, 出力電流 波形が上下にシフトされる。シフトされる量はスイッチン グ周期ピーク電流の変化量と同じであるため, 正のピーク 電流の変化を求めることでインダクタ平均電流の変化を取 得することが出来る。この動作モードでは，ハイサイドス イッチ $\mathrm{Q}_{1}$ がオンされるときに，インダクタ電流はゼロで あるため, 電圧指令 $\mathrm{V}_{\text {ref }}$ から計算されるオン時間の変化と インダクタ電流 di/dt の積から電流の変化量を求めることが できる。図 2 の制御ブロックに記載されるように変調率を $\mathrm{m}_{i n v}=V_{r e f} \cdot 2 / V_{d c}$ で計算することができ, $\mathrm{E}_{\mathrm{d}}$ は直流リンク 電圧 $\mathrm{V}_{\mathrm{dc}}$ の $1 / 2$ であるため，(1) 式により $\mathrm{Q} 1$ のオンデュー ティ比を(11) 式で求めることが出来る。

$$
\mathrm{D}=V_{r e f} /\left(E_{d} \cdot 2\right)+1 / 2
$$

コンデンサ電圧 $\mathrm{V}_{\mathrm{o}}$ を基準に $\left(V_{\text {ref }}-V_{o}\right)$ の電圧指令変化 があったときに， $\mathrm{V}_{\mathrm{ref}}$ と $\mathrm{V}_{\mathrm{o}}$ を(11) 式に代入してその差を 求めることで, デューティ比の変化は $\left(V_{r e f}-V_{o}\right) /\left(E_{d} \cdot 2\right)$ で あることが分かる。さらに，デューティ比の変化とスイッ チング周期 $\mathrm{T}_{\mathrm{C}}$ との積でスイッチ $\mathrm{Q}_{1}$ オン時間の変化を求 めることができ，電流変化率 $\mathrm{di} / \mathrm{dt}$ は $\left(E_{d}-V_{o}\right) / L$ であるた め, 電圧指令は $\mathrm{V}_{\mathrm{o}}$ から $\mathrm{V}_{\text {ref }}$ に変化した時に電流の変化量 $\Delta i_{i n v}$ が(12) 式で表すことができる。

$$
\Delta i_{i n v}=\frac{\left(V_{r e f}-V_{o}\right)}{E_{d} \cdot 2} \cdot T_{c} \cdot \frac{\left(E_{d}-V_{o}\right)}{L} .
$$

さらに，電圧指令 $\mathrm{V}_{\text {ref }}$ が $\mathrm{V}_{\mathrm{o}}$ と同じである場合に，イン バー夕電流はモード 2 の最小電流となって, 電流波形の負 側のピークは $-\delta_{p}$ であり, リップル電流の大きさは $i_{r}$ であ るため, インダクタ電流のスイッチング周期平均は (13) 式 で表すことができる。

$$
i_{\text {invMIN }}=i_{r} / 2-\delta_{p}
$$

(13) 式に示す電流值 $i_{i n v M I N}$ に (12) 式に示す電流変化量 を足すことで，(14) 式に示すモード 2 のインバー夕電流の 数式表現が得られる。

$$
\begin{aligned}
\bar{i}_{i n v} & =i_{i n v M I N}+\Delta i_{i n v} \\
& =\frac{i_{r}}{2}-\delta_{p}+\frac{\left(V_{r e f}-V_{o}\right)}{E_{d} \cdot 2} \cdot T_{c} \cdot \frac{\left(E_{d}-V_{o}\right)}{L} \cdots
\end{aligned}
$$

スイッチ $\mathrm{Q}_{1}$ と $\mathrm{Q}_{2}$ のターンオフ時間が同じとすれば, (14) 式を (7) 式に示す正誤差電圧 $\Delta V_{p}$ と (8) 式に示す正クラン プ電流 $\delta_{p}$ で表すと, (15) 式に示す電圧指令とインダクタ電 流との関係式を得ることができる。(15) 式から，インバー 夕電流がインバー夕電圧指令 $V_{r e f}$ の変化に比例に変化し, 抵抗のような動作特性であることが分かる。また，モード 2 の誤差電圧が (16) 式に示す範囲で変化する。

$$
\begin{aligned}
& \bar{i}_{i n v} \doteq \frac{i_{r}}{2}-\delta_{p}+\frac{\left(V_{r e f}-V_{o}\right)}{\Delta V_{p}} \cdot \delta_{p} \\
& 0<\Delta V<\Delta V_{p} \ldots \ldots \ldots \ldots \ldots
\end{aligned}
$$

また，インダク夕電流の周期平均が正であり，デッド夕 イム期間中にインダク夕電流がゼロになってから Q1 がオ ンされる場合に (9), (10) 式及び (14) 式が成立する。図 7 と図 8 に示す動作パターンがこれらの条件を満足している ため，いずれの場合も (9), (10) 式及び (14) 式の同一の式 で表現できる。

さらに，(15) 式において， $V_{r e f}=V_{o}+\Delta V_{p}$ の場合にイン ダク夕平均電流が $i_{r} / 2$ となり, モード 2 の電流上界である と同時にモード 1 の電流下界と一致する, 誤差電圧が同じ く $\Delta \mathrm{V}_{\mathrm{p}}$ であるため, モード 2 上界とモード 1 下界の誤差 電圧が一致することが分かる。

(3) モード $3:-i_{r} / 2+\delta_{n} \leq i_{i n v} \leq i_{r} / 2-\delta_{p}$ ここで, 


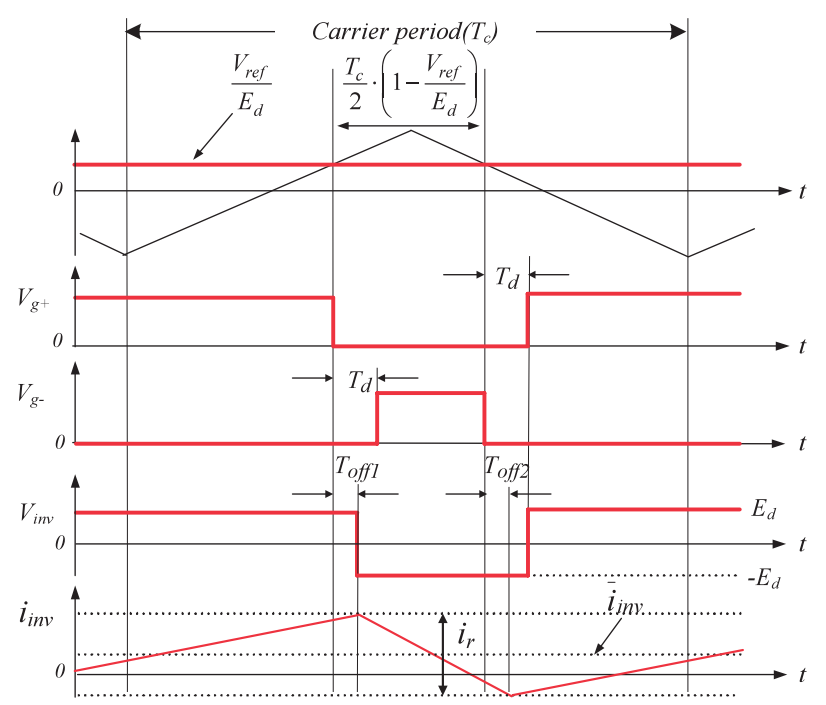

図 9 デッドタイム誤差電圧（モード 3 )

Fig. 9. Dead time error mode 3.

$\delta_{n}$ は (17) 式で定義し， $\delta_{p}$ のように, 交流電圧の変化とと もに值が変化する。

$$
\delta_{n}=\left(T_{d}+T_{o n 2}-T_{o f f 1}\right) \times \frac{\left(E_{d}+V_{o}\right)}{L}
$$

図 9 にモード 3 の PWM ゲート信号，インバータ端子電 圧，インダク夕電流の波形を示す。この動作モードに打い て一方のスイッチがオフされた時に反対側スイッチのダイ オードが自動にオンされるため，デッドタイム及び IGBT オン遅れの影響を受けず，デッドタイム誤差電圧が発生し ない。図 9 に示す動作波形を基に(18) 式に示すインバー夕 出力の平均電圧を求めることができる。誤差電圧及びイン バー夕電流がそれぞれを(19) 式と (20) 式に示す。ここで, スイッチ $\mathrm{Q}_{1}$ と $\mathrm{Q}_{2}$ のターンオフ時間が同じとすれば，誤差 電圧がゼロとなり，理想スイッチ特性が得られる。

$$
\begin{gathered}
\bar{V}_{i n v}=V_{\text {ref }}+\frac{T_{o f f 1}-T_{o f f 2}}{T_{c}} \cdot 2 \cdot E_{d} \\
\Delta V=\frac{T_{o f f 1}-T_{o f f 2}}{T_{c}} \cdot 2 \cdot E_{d} \doteq 0 \ldots \\
\bar{i}_{i n v}=\frac{V_{r e f}+\Delta V-V_{o}}{s L} \doteq \frac{V_{r e f}-V_{o}}{s L}
\end{gathered}
$$

また，モード 2 の電圧指令と電流との関係を示す (15) 式 において, $V_{r e f}=V_{o}$ の場合にインダク夕平均電流が $i_{r} / 2-\delta_{p}$ となり，モード 2 の電流下界であると同時に，モード 3 の電 流上界と一致する。誤差電圧についても，モード2下界の誤 差電圧がゼロであることはモード 3 の誤差電圧と一致する。

(4) モード $4:-i_{r} / 2<\bar{i}_{i n v}<-i_{r} / 2+\delta_{n}$ ここで, $\delta_{n}$ は前述の (17) 式に定義されている。この動作モードのイン バー夕出力電圧, 誤差電圧及びインバー夕電流はそれぞれ, (21) （23）式に示す。

$$
\begin{aligned}
& \bar{V}_{i n v} \doteq V_{o} \ldots \ldots \ldots \ldots \ldots \\
& \Delta V=\bar{V}_{i n v}-V_{r e f} \doteq V_{o}-V_{r e f}
\end{aligned}
$$

$$
\bar{i}_{i n v}=-\frac{i_{r}}{2}+\delta_{n}+\frac{\left(V_{r e f}-V_{o}\right)}{\Delta V_{n}} \times \delta_{n} .
$$

ここで, $\Delta V_{n}$ は後述するモード 5 の負誤差電圧であり, 式に定義される。

(5) モード $5: \bar{i}_{i n v} \leq-i_{r} / 2$ この動作モードのインバー 夕出力電圧, 誤差電圧及びインバー夕電流を (24) (26) 式 にそれぞれ示す。

$$
\begin{gathered}
\bar{V}_{i n v}=V_{r e f}+\frac{T_{d}+T_{o n 2}-T_{o f f 2}}{T_{c}} \cdot 2 \cdot E_{d} \ldots \ldots . \\
\Delta V_{n}=\bar{V}_{i n v}-V_{r e f}=\frac{T_{d}+T_{o n 2}-T_{o f f 2}}{T_{c}} \cdot 2 \cdot E_{d} \\
\ldots \ldots \ldots \ldots \ldots \ldots \ldots \ldots \ldots \ldots
\end{gathered}
$$

以上で, デッドタイム誤差電圧の動作解析を行った。モー ド1に拈いて, ハイサイドスイッチをオフした場合, ローサ イドのダイオードを通して, インバータ端子に負の電圧が印 加される。ローサイドスイッチのオン信号を出力しないこ とで, デッドタイムは必要しなくなるため, 八イ側スイッチ のオンデューティを $100 \%$ まで出力することができる。モー ド 5 の場合にも同様にロー側スイッチのオンデューティを 100\%まで出力することができる。

〈3・2〉 直流リンク電圧の設計方法 正弦波出力を条 件に，インバー夕出力電流の有効成分 Id と無効成分 Iq を 出力するために，(27) 式に示すインバー夕電圧が出力され る必要がある。

$$
V_{i n v R M S}=\sqrt{\left(V_{o R M S}-I_{q R M S} \cdot \omega \cdot L\right)^{2}+\left(I_{d R M S} \cdot \omega \cdot L\right)^{2}}
$$

ここで, $V_{\text {invRMS }}$ はLCフィルタ前のインバー夕出力電圧の 実効值, $V_{O R M S}$ はフィルタコンデーサ電圧の実効值， $\omega$ は 交流角周波数，LはLCフィルタのインダクタンスである。

デッドタイムを 0 とする場合は, インバータから出力で きる電圧は (28) 式で表すことができる。

$$
V_{\text {invRMS }}=\frac{E_{d}}{\sqrt{2}}
$$

ただし，デッドタイム誤差電圧 $\Delta V$ の影響を考慮する場合 は (29) 式で表すことになる。

$$
V_{\text {invRMS }}=\frac{E_{d}-\Delta V}{\sqrt{2}} \text {. }
$$

誤差電圧 $\Delta V$ は出力電流の大きさにより変化するもので あり，全領域の出力品質を保証するため，(27) 式及び (29) 式により求めると, (30) 式に示す直流リンク電圧が必要に なる。ここで, $V_{d c}=2 \cdot E_{d}$ である。

$$
V_{d c}=2 \cdot \sqrt{2} \cdot \sqrt{\left(V_{o R M S}-I_{q R M S} \cdot \omega \cdot L\right)^{2}+\left(I_{d R M S} \cdot \omega \cdot L\right)^{2}}+2 \cdot \Delta V
$$

即ち, 直流リンク電圧は誤差電圧の 2 倍を高くする必要が ある。誤差電圧 $\Delta V$ は (4) 式及び (25) 式で求めることはで きる。 


\section{4. 制御器設計}

デッドタイムの解析結果で, たとえば, 直流リンク電圧 は $350 \mathrm{~V}$ と仮定, $3 \mu \mathrm{s}$ のデッドタイム時に $18.9 \mathrm{~V}$ の誤差電 圧が発生することになる。理想な制御を得るため, 短時間 内に応答する必要があるため, 通常の線形モデルで検討し た制御で実現するのは困難である。本論文で, 線形動作領 域にPI 制御を動作させて, 非線形動作が検出されたとき, スライディングモード制御を動作させることで, 出力特性 の改善を図る。

〈4·1〉従来のスライディング制御法の説明 (31) 式 に従来のスライディング制御 $(\mathrm{SMC})$ の切替関数を示す ${ }^{(12)}$ 。

$$
S=K \cdot e+\dot{e}=0
$$

状態変数をスライディング平面上に動作させるように， ゲート信号を作成する。作成方法は (32) 式に示す。

$$
u=\left\{\begin{array}{lll}
1 & \text { for } & s>+\varepsilon \\
0 & \text { for } & s<-\varepsilon
\end{array}\right.
$$

ここで，演算結果はスイッチング素子のゲート信号に相当 するものであり， $\varepsilon$ はスイチィング周波数を制限するため のヒステリシスである。状態変数を常に監視する必要があ り，デジタル制御を行う場合，スイチイング周波数よりはる かに高い周波数でサンプリングするにはFPGA などのハー ドウエア演算装置が必要である。

〈4・2 〉提案法の構成 図 10 に, 提案法の制御ブロッ ク図を示す。線形動作領域ではPIによる制御を施すものと し，デッドタイム非線形動作が検出されたときにはスライ ディングモードで制御するものとする。両方の足し合わせ で PWM 制御のデューティ信号を生成する。さらに，スラ イディング制御に必要な誤差電圧信号をオンライン自動調 整することで, 回路パラメータ及び動作条件変化への適応 制御を行う。

これから，スライディングモード制御の実現方法を説明 する。
スライディングモード切替関数は, 従来, 制御誤差及び 誤差の微分で演算されるので, 演算結果が非常に小さい值 となり，ノイズの影響を受けやすい。そこで，ノイズの影 響を避けるために切替関数 ((27) 式)に積分演算を行い, 安 定な動作を図るようにした。従って, 新しい切替関数は以 下のようになる。

$$
S=K \cdot \int e+e-S_{0}=0
$$

さらに, PI 制御がスライディングラインに沿って, 動作 させるため, $\mathrm{K}=\mathrm{K}_{\mathrm{i}} / \mathrm{K}_{\mathrm{p}}$ にすることができる。ここで, $\mathrm{K}_{\mathrm{p}}$ 及び $\mathrm{K}_{\mathrm{i}}$ はそれぞれ PI 制御器の比例ゲインと積分ゲインで ある。 $\mathrm{K}_{\mathrm{p}}$ 及び $\mathrm{K}_{\mathrm{i}}$ を使用して (33) 式を書き直すと，(34) 式 に示す新しい切替関数を得られる。

$$
S^{\prime}=K_{i} \cdot \int e+K_{p} \cdot e-S_{0}^{\prime}=0 \cdot
$$

(34) 式の第 1 項と 2 項には PI 制御器の演算結果を使用 することとし， $S_{0}^{\prime}$ は次の (35) 式で演算する

$$
S_{0}^{\prime}=L \cdot \frac{d i}{d t}=L \cdot \frac{\left(i_{n}-i_{n-1}\right)}{T_{c}}
$$

ただし, L はインダクタのインダクタンスであり, $T_{c}$ はス イッチング周期, $i_{n}$ と $i_{n-1}$ はそれぞれ, インダク夕電流の 今回と前回のサンプリング值である。

スライディングモードコントローラは (34) 式の結果に対 して, (36) 式で定義される演算を行い, その演算結果を出 力する。式に記載される条件が全て満足されていない場合 はそれ以前の制御量を保持することとする。

$$
u_{n}=\left\{\begin{array}{lll}
\Delta V_{p} & \text { for } & (S>\varepsilon) \text { and }\left(u_{n-1} \geq 0\right) \\
0 & \text { for } & \left((S>\varepsilon) \text { and }\left(u_{n-1}<0\right)\right) \text { or } \\
& & \left((S<-\varepsilon) \text { and }\left(u_{n-1}>0\right)\right) \\
-\Delta V_{n} & \text { for } & (S<-\varepsilon) \text { and }\left(u_{n-1} \leq 0\right)
\end{array}\right.
$$

ここで, $\varepsilon$ はチッタリング防止のヒステリシスである。

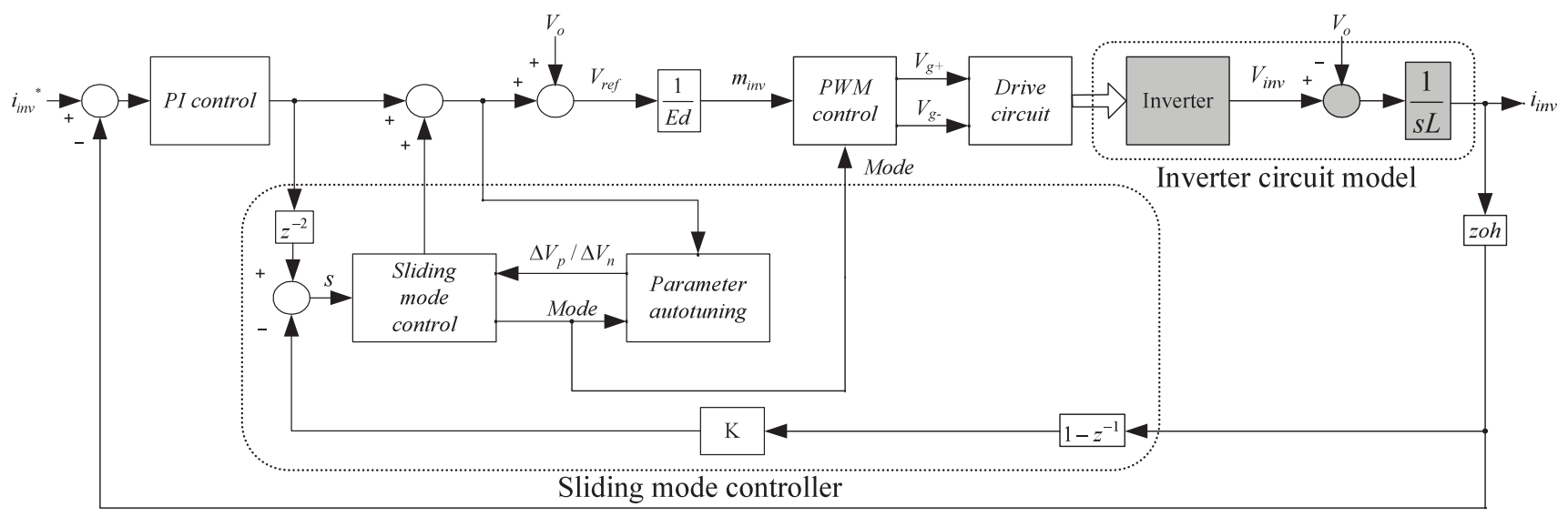

困 10 提案法の制御ブロック図

Fig. 10. Proposed controller configuration. 
〈4·3〉 スライディングモード制御パラメータの自己調 整方法スライディングコントローラでは正の誤差電圧 $\Delta V_{p}$ 及び負の誤差電圧 $\Delta V_{n}$ が使用されている。それらの值 は，デッドタイム，直流リンク電圧及びスイッチング素子 の $\mathrm{ON} \cdot \mathrm{OFF}$ 遅れ時間に影響される。

これから, 誤差電圧の演算方法を説明する, 図 11 に交流 周期の制御信号の出力例を示す。上部の部分にスライディ ング制御の出力, 下部の部分に PI 制御出力とスライディン グモード制御出力の加算結果を示す。

PWM 変調信号を演算するためのインバー夕電圧指令は (37) 式に示す。

$$
V_{r e f}=u_{p i}+u_{s m c}+V_{o}
$$

ここで, $u_{p i}$ 及び $u_{s m c}$ はそれぞれ PI 制御器及びスライディ ングモード制御器の出力である。

䛊差電圧 $\Delta V$ を含んで，インバー夕制御指令と電流の関 係として，(38) 式が成立する。

$$
V_{\text {ref }}=L \cdot \frac{d i}{d t}+\Delta \mathrm{V}+V_{o}
$$

また，スライディングモード制御器が正誤差電圧を出力 している間，時間 $\mathrm{t}_{1}$ の電流を $i_{(t 1)}$ とすると，時間 $\mathrm{t}_{2}$ におけ る電流 $i_{(t 2)}$ は (39) 式のようになる。

$$
i_{(t 2)}=\int_{t 1}^{t 2} \frac{u_{p i}+u_{s m c}-\Delta V}{L} d t+i_{(t 1)}
$$

ここで，電流 $i_{(t 1)}$ と $i_{(t 2)}$ は同じで，リップル電流の $1 / 2$ で あるので，(40) 式が得られる。

$$
\Delta V=\frac{\int_{t 1}^{t 2}\left(u_{p i}+u_{s m c}\right) d t}{t_{2}-t_{1}}
$$

ここで, $t_{1} \sim t_{2}$ 間の制御量 $\left(u_{p i}+u_{s m c}\right)$ の平均演算で正誤 差電圧を求めることとし, $t_{3} \sim t_{4}$ 間の制御量で負誤差電圧 を求める。これらの演算結果でスライディングモード制御 のパラメータを調整する。

上記演算で得られた誤差電圧には回路素子の電圧降下も 含まれているが，デッドタイム誤差電圧に比べて充分に小

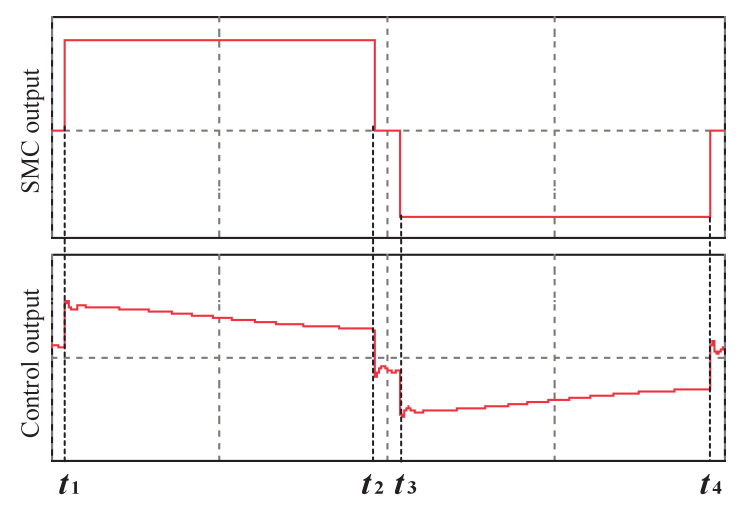

図 11 パラメータ自動調整

Fig. 11. Parameter auto-tuning.
さい值なので, 回路素子のカタログのパラメータで補正す るに留める。

\section{5. シミュレーション結果}

デッドタイムの数式モデル及び提案する方法の制御特性 を確認するためにシミュレーション検証を行った。従来の PI 制御を比較対象として, 出力電流および直流リンク電圧 が変化した時の動作比較を行い，提案方法の有効性を述べ る。表 1 にシミュレーションに用いるパラメータを示す。

デッドタイム数式モデルを検証するため, オープンルー プ電圧制御のシミュレーションを行った。負荷条件が定格 50\%の抵抗負荷であり，図 12(a) にデッドタイム補償を行 わないときのオープンループ動作波形を示し, 図 12(b)に 導出したデッドタイムモデルを基にデッドタイム補償を行 う場合のシミュレーション動作波形を示す。上段から下段 までの波形はそれぞれ, 電圧変調指令 $\mathrm{V}_{\mathrm{ref}}$ /出力コンデンサ 電圧 $\mathrm{V}_{\mathrm{o}}$, インダクタ電流及び負荷出力電流を示す。デッド タイム補償を行わない場合はゼロクロスの正側と負側に, 波形歪みが発生し, 電圧指令に比べ, 低い電圧が出力され る。また，ゼロクロス付近でデッドタイム誤差が発生しな いため, 電流極性によるデッドタイム補償を行うと逆に出 力品質が悪化する恐れがある。

続いて，シミュレーション動作波形を用いて，PWM ゲー ト制御方法及びデッドタイム補償効果を説明する。図 13 に提案法の定格 50\%出力時のシミュレーション結果と動作 モード切替の時の拡大波形を示す。上段から下段までの波 形はそれぞれ, 系統電圧, PI コントローラ出力信号／スラ イディングモードコントローラ制御信号, ハイサイド IGBT ゲート信号／ローサイドIGBT ゲート信号, インダクタ電 流, AC フィルタの出力側の電流である。スライディング モードコントローラ $(\mathrm{SMC})$ が正の值を出力している間に, ローサイドIGBT の PWM ゲート信号を停止し, デッドタ イムを挿入せずにハイサイドIGBT の制御を行っている。 $\mathrm{SMC}$ コントローラが負の值を出力しているときに, ハイ サイドIGBT の PWM ゲート信号を停止し, デッドタイム を挿入せずにローサイドIGBT の制御を行っている。SMC コントローラの出力がゼロである時に, 従来制御と同じく, デッドタイムを挿入しながら, 上下スイッチの PWM オン

\begin{tabular}{|c|c|}
\hline Output filter inductor & $1 \mathrm{mH}(3.1 \% \mathrm{Z})$ \\
\hline Output filter capacitor & $20 \mathrm{uF}(15.9 \% \mathrm{Z})$ \\
\hline Carrier frequency & $20 \mathrm{kHz}$ \\
\hline Dead time & $2 \mu \mathrm{s} / 3 \mu \mathrm{s} / 4 \mu \mathrm{s}$ \\
\hline Rated output power & $2 \mathrm{kVA}(1 \varphi 3 \mathrm{~W})$ \\
\hline Utility voltage & $1 \varphi 3 \mathrm{~W} \mathrm{AC} 100 \mathrm{~V} / 200 \mathrm{~V}$ \\
\hline Utility frequency & $50 \mathrm{~Hz}$ \\
\hline DC link voltage & $290 \mathrm{~V} / 320 \mathrm{~V} / 350 \mathrm{~V}$ \\
\hline
\end{tabular}
／オフを制御している。拡大波形に示すように，提案方法

表 1 システムパラメータ

Table 1. System parameters. 


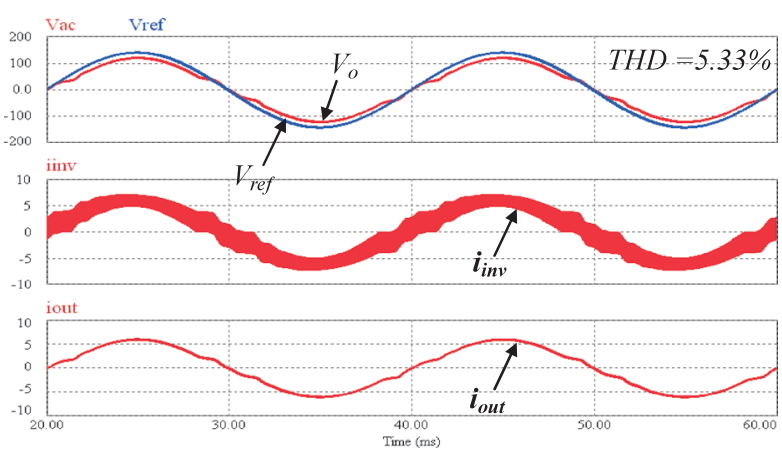

(a) Without dead-time compensation

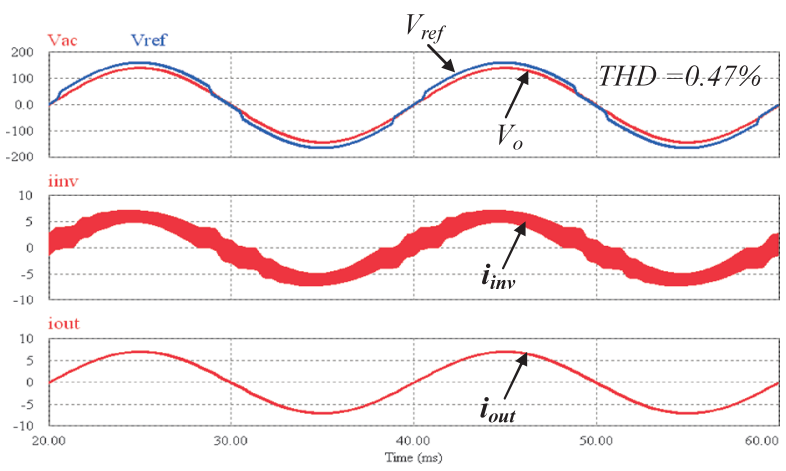

(b) Compensation with proposed model

図 12 オープンループ電圧制御

Fig. 12. Open loop voltage control.
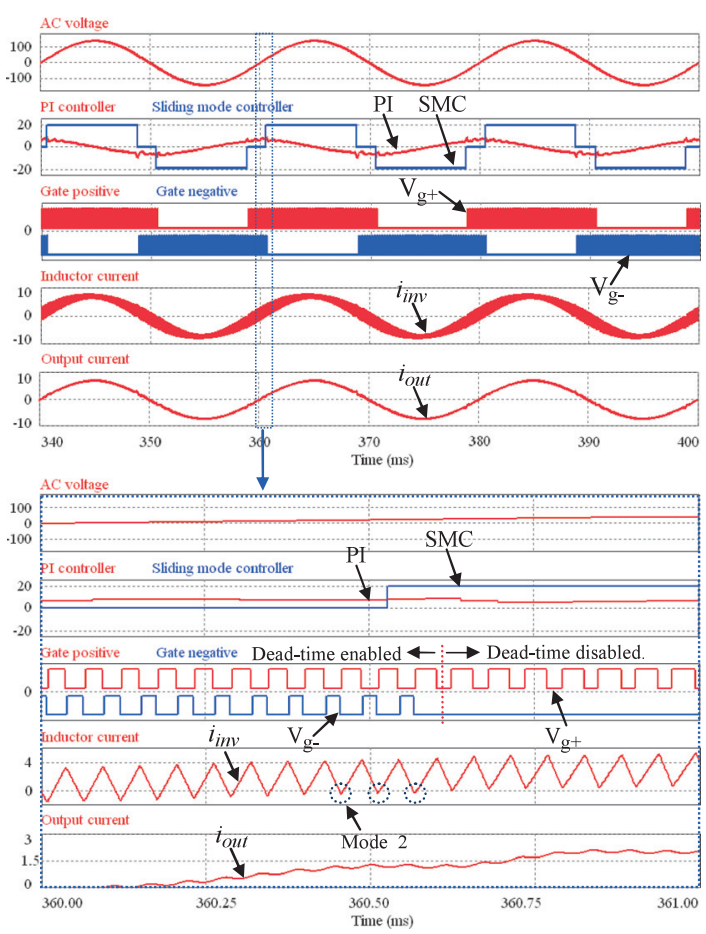

図 13 提案法動作波形

Fig. 13. Operation waveforms with proposed control.

がモード 2 とモード 4 の非線形動作を短時間に検出するこ とができるため，高速にモード切替を行うことができる。 これによりデッドタイムの悪影響を排除し, 低歪みな出力 波形が得られている。
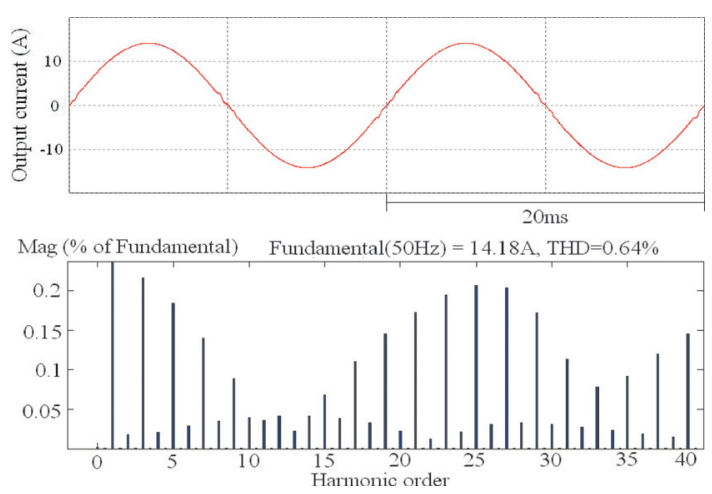

図 14 出力電流波形及び高調波解析

Fig. 14. Output current \& Harmonic spectrum.

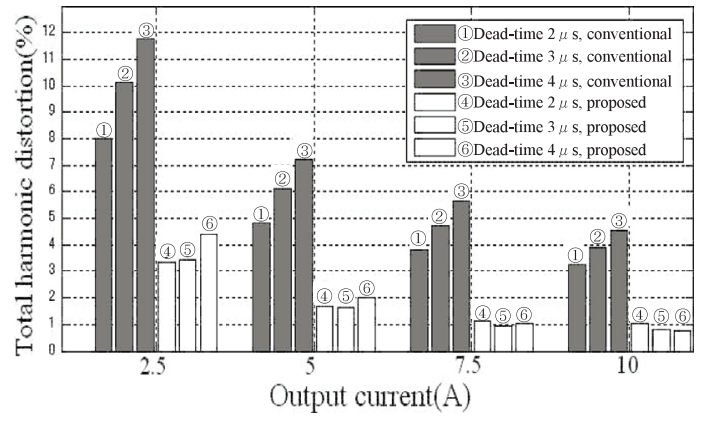

図 15 デッドタイム変化時の高調波歪み比較

Fig. 15. THD with variations in dead time.

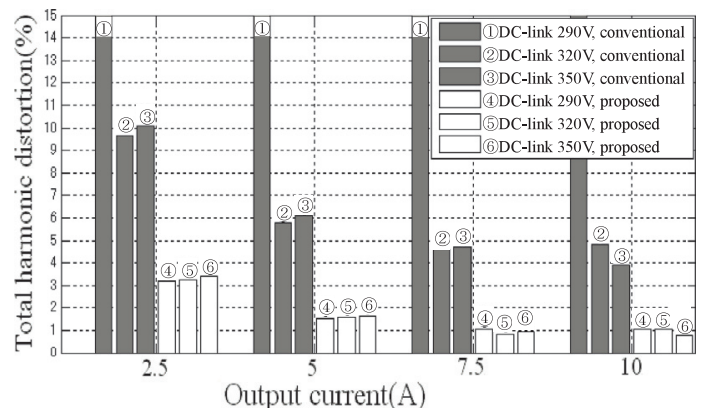

図 16 直流リンク電圧変化時の高調波歪み比較

Fig. 16. THD with variations in DC Link voltage.

図 14 に提案法の定格出力時のシミュレーション結果を 示す。従来のPI 制御に比べてゼロクロス前後の波形が大き く改善され, 総合歪み率が従来のPI 制御の約 $1 / 3$ となり, 非常に良好な結果が得られている。

続いて, 出力電流, 実効デッドタイムおよび直流リンク 電圧が変化した時に対しても, 従来の PI 制御と提案法の比 較を行う。

図 15 に実効デッドタイムが $3 \mu \mathrm{s}$ を中心に $\pm 1 \mu \mathrm{s}$ で変化 する時, 各負荷点において, 従来の PI 制御と提案法の高調 波含有率の比較結果を示す。デバイスのバラツキ及び動作 条件変化により実際のデッドタイム時間が大きく変化して も, 安定な改善効果が得られている。全ての出力領域にお いて電流歪みが従来法の約 $1 / 3 \sim 1 / 2$ まで改善されている。 


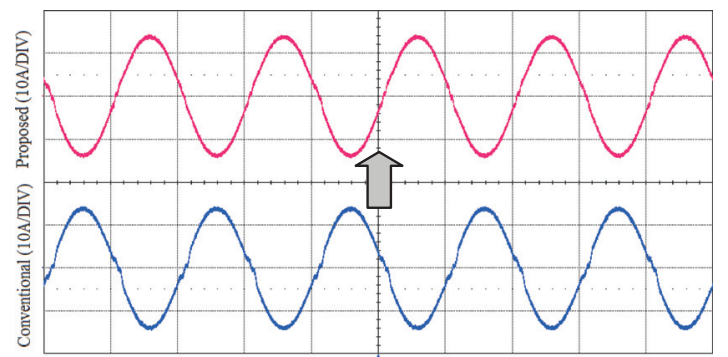

(a) Output current waveform (10 Arms)

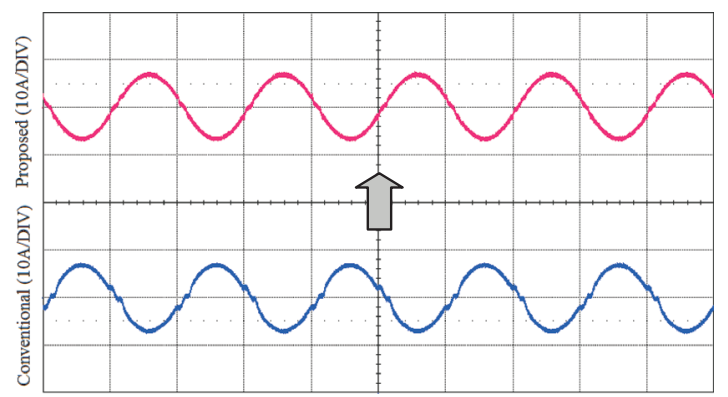

(b) Output current waveform (5 Arms)

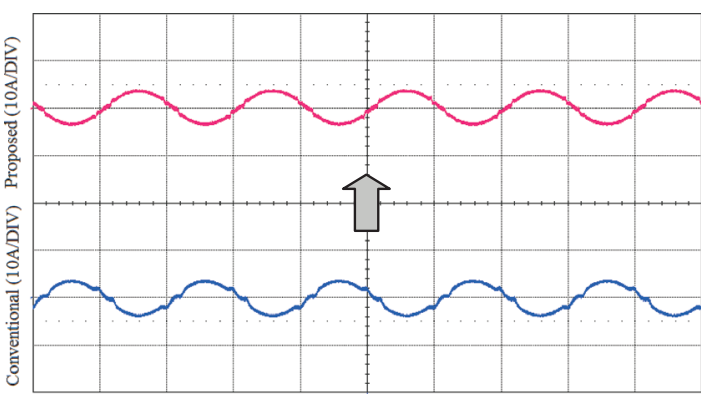

(c) Output current waveform (2.5 Arms)

図 17 従来法と提案法の電流波形比較（実験）

Fig. 17. Experimental output current waveform.

図 16 に直流リンク電圧を変化させたときのシミュレーシ ヨン結果を示す。直流リンク電圧を $290 \mathrm{~V} \sim 320 \mathrm{~V} \sim 350 \mathrm{~V}$ の範囲で変化させたとき, 直流リンク電圧が低い領域, 従 来制御は正常動作できないに対して, 提案方法は全ての電 圧及び負荷領域で電流歪み率が従来のPI 制御の約 $1 / 3$ まで 改善できている。

制御器のパラメータは変更せずにシミュレーション検証 を行ったため, 動作条件変化と回路パラメータ変化の影響 を殆ど受けないことを確認できる。

\section{6. 実験検証}

〈6・1〉実験条件提案する制御方法を図 1 に示す回 路と表 1 の回路パラメータで実験検証を行う。デッドタイ ム $=3 \mu \mathrm{s}$, 昇圧 $\mathrm{DC} / \mathrm{DC}$ コンバータの入力電圧 $=160 \mathrm{~V}$ の 条件で提案法と従来法との比較を行う。商用電源は安定な 擬似交流電源，同じ実験装置に制御プログラムの書き換え だけであるため, 装置のバラツキ及び動作条件変化による 影響はないと考える。

〈6・2〉高調波歪み改善図 17(a), 図 17(b) 及び

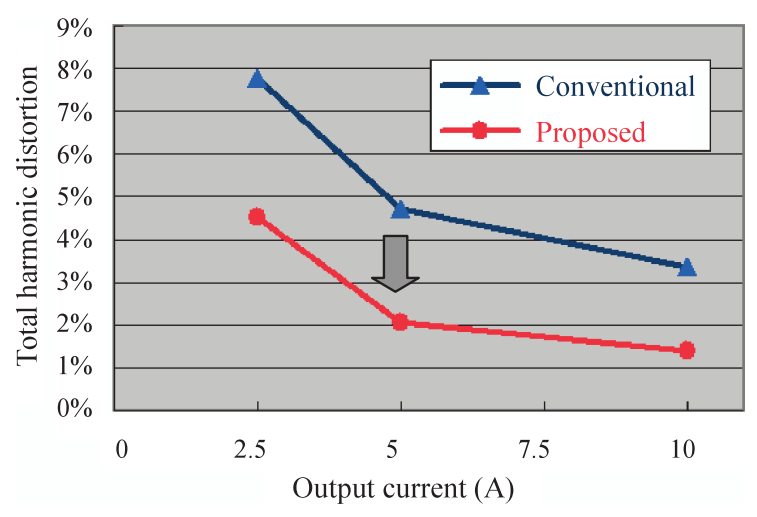

図 18 出力電流高調波歪み率改善 (実験結果)

Fig. 18. Improvements in harmonic distortion.

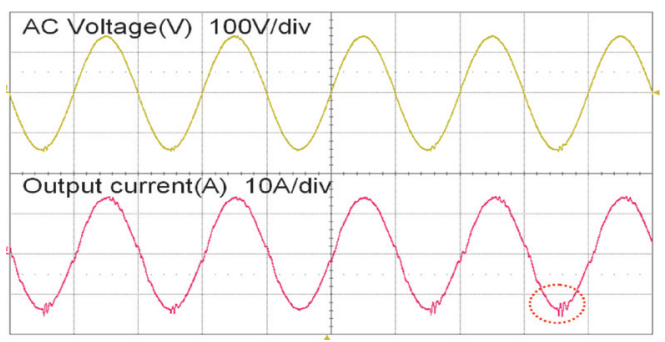

図 19 従来方法の実験波形

(直流リンク電圧 $=320 \mathrm{~V}$ )

Fig. 19. Experimental waveform of conventional ( $\mathrm{Vdc}$ $=320 \mathrm{~V})$.

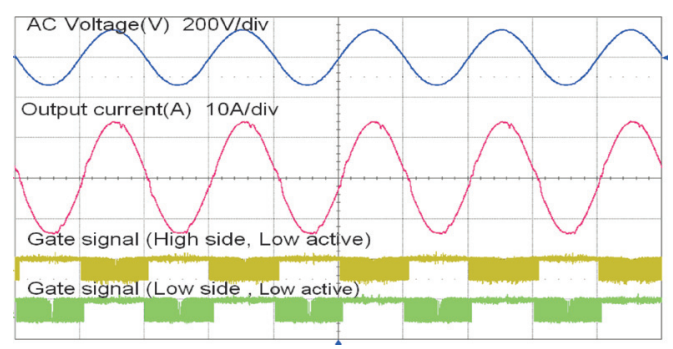

図 20 提案方法の動作波形

(直流リンク電圧 $=288 \mathrm{~V}$ )

Fig. 20. Experimental waveform of the proposed (Vdc $=288 \mathrm{~V})$.

図 17(c) に提案方法と従来方法の出力電流波形比較を示す。 図 18 に高調波歪みの改善効果を示す。全負荷領域の電流 歪み率が PI 制御の約 $1 / 3 \sim 1 / 2$ まで改善できている。

〈6・3 直流リンク電圧低減図 19 に直流リンク電圧 が $320 \mathrm{~V}$ である時の従来方法の出力電流波形, 図 20 に直 流リンク電圧が $288 \mathrm{~V}$ である時の提案方法の出力電流波形 を示す。 $320 \mathrm{~V}$ と $288 \mathrm{~V}$ はそれぞれ, 従来方法と提案方法 の直流リンク電圧限界值であり, 約 $32 \mathrm{~V}$ の直流リンク電圧 低減効果が得られている。

$\langle 6 \cdot 4\rangle$ 変換効率改善 提案方法は $30 \mathrm{~V}$ 以上の直流り ンク電圧低減効果を確認できたため, 直流リンク電圧を現 状の $350 \mathrm{~V}$ から $320 \mathrm{~V}$ に変更して, 变換効率の実験デー夕 を取得した。図 21 に提案方法と従来方法の変換効率比較 


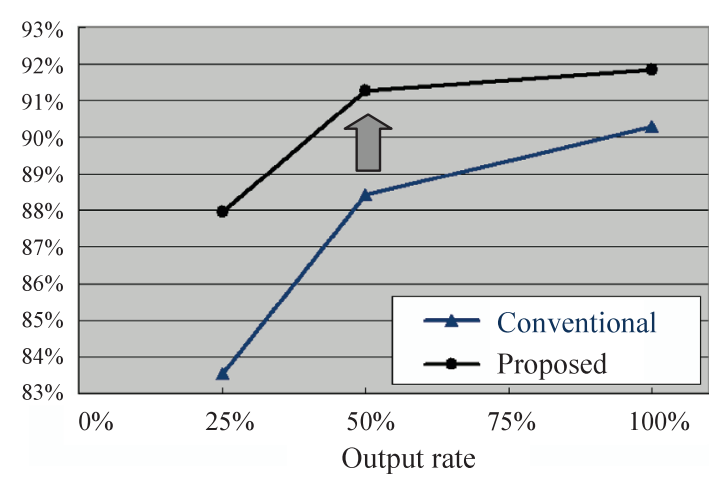

図 21 効率改善効果

Fig. 21. Improvements in conversion efficiency.

を示す。定格出力時に約 $1.6 \%$ の効率改善ができている。

\section{7. まとめ}

以上, LC フィルタ付系統連系インバータのデッドタイ ムにより生じる誤差電圧のメカニズムを明らかにし，イン バータの動作を数式で表現することができた。この数式モ デルを基に, 新しいスライディングモード制御器を提案し, シミュレーション及び実験結果により提案方法の有効性を 確認できた。結果を要約すると以下のようになる。

（1）インバータデッドタイムおよびスイッチング素子 の動作遅れによる回路動作は 5 つの動作モードに分かれる。 また，それらの各モードにおける数式表現を明らかにした。

（2）得られた数式モデルを基に新しいスライディング モード制御器を提案し，高調波歪みを改善すると共に，直 流リンク電圧の低減と変換効率の向上を図った。

（3） スライディングモード制御パラメータの自己調整 方法を提案し, 回路パラメータ及び動作条件変化への適応 制御を実現した。

(4) PI 制御器とスライディングモード制御器を併用す ることで，全負荷領域に電流歪み率がPI 制御の約 $1 / 3 \sim 1 / 2$ まで改善できることをシミュレーションと実験検証で確認 した。

（5）直流リンク電圧の約 10\%の低減効果と約 $1.6 \%$ の 効率改善を実験検証で確認できた。

(平成 21 年 3 月 25 日受付，平成 21 年 9 月 11 日再受付)

\section{文献}

(1) J. Kang, G. Xu, J. Xu, and C. Zhou: "Study of compensation method on dead-time effects for VSI fed drive systems", IEEE PESC Record, pp.548552 (2007-6)
(2) A.R. Munoz and T.A. Lipo: "On-line dead time compensation technique for open-loop PWM-VSI drives", IEEE Trans. on Power Elec., Vol.14. No.4. pp.683-689 (1999-7)

(3) D. Leggate and R.J. Kerkman: "Pulse based dead time compensator for PWM voltage inverter", IEEE Trans. on Industrial Electronics, Vol.44, No.2, pp.191-197 (1997-4)

(4) N. Urasaki, T. Senjyu, K. Uezato, and T. Funabashi: "On-line dead-time compensation method for voltage source inverter fed motor drives", in Proc. IEEE APEC, pp.122-127 (2004-2)

(5) B. Zhou, W.H. Lau, and H. Chung: "The analysis of a novel dead-time generation and compensation method for 2-level PWM topology", IEEE PESC Record, pp.1543-1547 (2006-6)

(6) J. Itoh, T. Fujii, T. Hoshino, A. Odakaand, I. Sato, and D. Tanaka: "Analysis of dead-time compensation method using disturbance observer for vector control", IEEJ Trans. on Industrial Application, Vol.128, No.8, pp.10051012 (2008-8) (in Japanese)

伊東淳一 ·藤井崇史 ·星野哲馬 - 小高章弘 ·佐藤以久也 $\cdot$ 田中大輔 : 「ベクトル制御における外乱オブザーバを用いたインバータ出力電 圧の誤差補償手法の解析」, 電学論 D, 128, 8, pp.1005-1012 (2008-8)

( 7 ) T. Hoshino and J. Itoh: "Analysis of dead-time error correction properties for V/F control with disturbance observer", Proc. of IEEJ IAS, Vol.1, pp.179 182 (2006-8) (in Japanese)

星野哲馬・伊東淳一:「外乱オブザーバを用いたインバータのデッドタ イム誤差補償の解析」, 平 18 産業応用部大, Vol.1, pp.179-182 (2006-3)

(8) M.H. Bierhoff and F.W. Fuchs: "Semiconductor losses in voltage source and current source IGBT converters based on analytical derivation", IEEE PESC Record, pp.2836-2842 (2004-6)

(9) S. Kouro, M. Perez, H. Robles, and J. Rodriguez: "Switching loss analysis of modulation methods used in cascade $\mathrm{H}$ bridge multilevel converters", IEEE PESC Record, pp.4662-4668 (2008-6)

(10) A.M. Hava, R.J. Kerkman, and T.A. Lipo: "Carrier-based PWM-VSI overmodulation strategies: analysis, comparison, and design", IEEE Trans. on Power Elec., Vol.13. No.4. pp.674-689 (1998-7)

（11）日本電気協会：分散型電源系統連系技術指針,第 2 章, オーム社 (2001)

(12) A.G. Perry, G. Feng, Y.-F. Liu, and P.C. Sen: "A new sliding mode like control method for buck converter”, IEEE PESC Record, pp.3688-3693 (20046)

郭 為 (正員) 1968 年 1 月 29 日生。1991 年 6 月中国

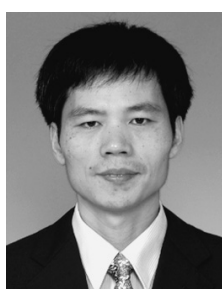
南開大学大学院修士課程修了。現在，新電元工業 (株) 及び長崎大学大学院生産科学研究科博士後期 課程に属し，インバータ制御の研究開発に従事。

黒 川 不二雄 (上級会員) 1976 年 3 月福岡工業大学工学部電

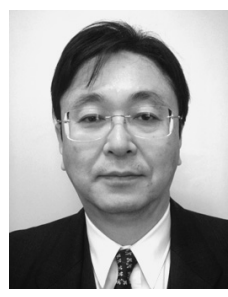
子工学科卒業。1977 年同大工学部助手, 1984 年 長崎大学工学部助手, 1994 年同大工学部助教授。 工博。この間，電子機器用電源，高速デジタル制 御, 太陽光発電システム, 照明用電子安定器, 口 ボット制御，高速カラー画像識別システム等の研 究に従事。電子情報通信学会, 情報処理学会, 映 像情報メディア学会, 照明学会, IEEE 各正員。 